\title{
SARKOPENIA - MARGINALIZOWANY PROBLEM WIEKU PODESZŁEGO
}

\author{
SARCOPENIA - A MARGINALIZED PROBLEM OF THE OLD AGE \\ Marzanna Mziray ${ }^{1}$, Regina Żuralska ${ }^{1}$, Magdalena Siepsiak², Przemysław Domagała ${ }^{3}$ \\ ${ }^{1}$ Zakład Pielęgniarstwa Społecznego i Promocji Zdrowia \\ Gdański Uniwersytet Medyczny \\ ${ }^{2}$ Katedra i Klinika Gastroenterologii i Hepatologii \\ Gdański Uniwersytet Medyczny \\ ${ }^{3}$ Zakład Zarządzania w Pielęgniarstwie \\ Gdański Uniwersytet Medyczny
}

DOI: https://doi.org/10.20883/pielpol.2017.69

\begin{abstract}
STRESZCZENIE
Sarkopenia to postępująca wraz z wiekiem utrata tkanki mięśniowej; proces ten przyczynia się do pogorszenia funkcji mięśni, zwiększając ryzyko upadków, złamań kości, nasilenia niepełnosprawności oraz uzależnienia od osób drugich. Wobec demograficznego wzrostu liczby osób starszych, także w strukturze społeczeństwa polskiego, sarkopenia zasługuje na uwagę. Uznaje się, że rozpowszechnienie sarkopenii jest niedoszacowane. Zaniedbanie tego problemu przynosi poważne skutki indywidualne, takie jak osłabienie siły mięśniowej czy zwiększenie ryzyka upadków oraz związane z nimi powikłania. Również dla całego systemu ochrony zdrowia ma istotne znaczenie ekonomiczne, dlatego jego wczesne rozpoznanie powinno być priorytetem w opiece geriatrycznej. W artykule przedstawiono genezę pojęcia, obraz kliniczny, powikłania, techniki przydatne w ocenie masy mięśniowej oraz postępowanie terapeutyczne.
\end{abstract}

SŁOWA KLUCZOWE: sarkopenia, osoby w wieku podeszłym, geriatria.

\section{Wstęp}

Aktualne prognozy demograficzne prezentują stały wzrost udziału osób starszych w strukturach większości społeczeństw świata. Tendencję tę również obserwuje się w Polsce.

Szacuje się, że do 2050 roku osoby po 65. roku życie będą stanowiły około jednej trzeciej ludności Polski [1]. Przewiduje się, iż tempo starzenia w Polsce będzie najszybsze spośród wszystkich państw Unii Europejskiej. Aktualny odsetek osób w wieku 65 lat i więcej w Europie to $17,1 \%$, a więc jest on większy niż w naszym kraju, ale w roku 2060 będzie to $30,0 \%$, czyli o ponad 6\% mniej niż w Polsce [2].

Współczesne koncepcje starzenia odrzucają pogląd, że sam proces starzenia powoduje powstawanie chorób. Starzenie się organizmu ludzkiego jedynie

\begin{abstract}
Sarcopenia is defined as a loss of a muscle tissue progressing with age. It contributes to the deterioration of the muscle function, increasing the risk of falls, fractures, the severity of disability and dependence on others. On account of the increased number of elderly people, also in the demographic structure of the Polish society, sarcopenia requires attention. It is recognized that the prevalence of sarcopenia is underestimated. Neglecting this problem can be the reason for serious consequences, such as the muscle weakness or increase in the risk of falls and related complications. Also, for the entire health system it has significant economic importance. Its early detection should be a priority in geriatric care. The article presents the genesis of the concept, clinical symptoms, complications, techniques useful in the evaluation of muscle mass and therapeutic methods.
\end{abstract}

KEYWORDS: sarcopenia, aged, geriatrics.

stwarza warunki sprzyjające występowaniu patologii, w tym niesprawności [3]. Nie budzi wątpliwości fakt, że sprawna starość jest najbardziej pożądana, ponieważ zapewnia samodzielność i niezależność, a tym samym zmniejsza zapotrzebowanie na pomoc ze strony otoczenia, również w zakresie opieki medycznej oraz usług pielęgnacyjno-opiekuńczych. Zagrożeniem jednak dla sprawnej starości jest typowa dla tego okresu życia wielochorobowość i wynikająca z niej polipragmazja. Do niesprawności w sposób znaczny przyczyniają się również wielkie zespoły geriatryczne, czyli częste w starości przewlekłe i wieloprzyczynowe patologie sprzyjające niesamodzielności. Należą do nich m.in. otępienie, depresja, upadki, zaburzenia wzroku i słuchu czy nietrzymanie moczu. Ostatnio coraz częściej zalicza się do nich również sarkopenię $[4,5]$. 
Szacuje się, iż problem sarkopenii u osób starszych mieszkających w środowisku domowym, w zależności od przyjętych kryteriów rozpoznawania (m.in. rodzaju wskaźnika wykorzystanego w procedurze identyfikacyjnej, przyjętych punktów odcięcia dla różnych kryteriów niskiej masy mięśniowej, a także przyjętej przez badaczy definicji sarkopenii) waha się od kilku do nawet kilkudziesięciu procent i wyraźnie narasta wraz z wiekiem $[6,7]$. W przypadku gdy sarkopenia definiowana jest wyłącznie jako związany z wiekiem spadek masy mięśniowej, jej rozpowszechnienie szacuje się od 5-13\% u osób w wieku 60-70 lat i do 11-50\% u osób powyżej 80. roku życia [8]. Powszechnie uważa się, że jej częstość występowania wyraźnie wzrasta wśród pacjentów hospitalizowanych [9-11] i instytucjonalizowanych [12-15].

Sarkopenia potęguje niebezpieczeństwo upadków i urazów, pogłębia niepełnosprawność oraz zależność od osób drugich [4, 5]. Może ponadto stanowić część składową innego, groźnego w następstwach, zespołu geriatrycznego - syndromu słabości. Konsekwencją sarkopenii są częste hospitalizacje i konieczność umieszczenia seniora w placówkach opieki długoterminowej. W istotny sposób obciąża to finanse rodzinne, a także budżet ochrony zdrowia. Niezahamowana sarkopenia przyczynia się do zwiększenia śmiertelności [16-18].

\section{Wpływ starzenia na masę i siłę mięśniową}

Typową cechą naturalnego starzenia się są zmiany w składzie ciała. Widzimy je zarówno w zakresie tkanki tłuszczowej, jak i w zakresie tkanki mięśniowej [19]. Masa mięśni zmniejsza się po 50. roku życia średnio o około $6 \%$ na każdą dekadę. Wobec tego u przeciętnego 85-latka ulegnie ona redukcji niemal o jedną czwartą (24\%) w odniesieniu do poziomu, który przedstawiał on w 45. roku życia [20]. W grupie osób starszych zauważono jednak osobnicze odmienności w szczytowej masie mięśni szkieletowych i w tempie, w którym zachodzi ich redukcja, co potwierdza zauważalną w grupie osób po 65. roku życia znamienną dla niej heterogeniczność [21].

Udowodniono, że intensywniej zanika masa mięśni u mężczyzn, mimo że przeciętnie charakteryzują się oni początkowo większą ich masą [22]. Dodatkowo dowiedziono, że zarówno u kobiet, jak i u mężczyzn utrata masy mięśniowej w kończynach dolnych jest większa niż w kończynach górnych. Sytuację tę częściowo wyjaśnia się obniżeniem aktywności fizycznej w populacji osób starszych, która intensywniej z zasady angażuje mięśnie dolnych części ciała [21]. Jeszcze szybciej niż masa mięśni zmniejsza się ich siła. Udowodniono, że w wieku między 50. i 60. rokiem życia spada ona w tempie $1,5 \%$ na rok, natomiast po 60 . roku życia - średnio o 3\% rocznie [23]. Przekłada się to na zwiększone ryzyko upadków, gorszą mobilność, a także pogorszenie ogólnej sprawności fizycznej nawet przy braku patologii.

\section{Geneza pojęcia „sarkopenia”}

Określenie „sarkopenia” po raz pierwszy zastosował w 1989 roku I. Rosenberg, definiując ją jako związany z wiekiem spadek masy mięśniowej [24]. Nazwa „sarkopenia" pochodzi z języka greckiego od wyrazów sarx „ciało” i penia - „strata”. Europejska Grupa Robocza ds. Sarkopenii u Osób Starszych (the European Working Group on Sarkopenia in Older People - EWGOSP) wydała w 2010 roku Europejski konsensus w sprawie definicji i diagnostyki sarkopenii. Definiuje on sarkopenię jako zarówno utratę masy mięśniowej, jak również idące za tym obniżenie funkcji mięśni jako tkanki [25]. Liczne późniejsze badania wykazały, że związana z wiekiem utrata siły mięśniowej może być tylko częściowo wyjaśniona zmniejszeniem ich masy, w związku z czym część naukowców domaga się, aby utratę masy mięśniowej i siły mięśniowej definiować niezależnie, stosując odpowiednio pojęcie sarkopenii w pierwszym przypadku, a dynapenii w drugim [26]. Według niektórych określenie „sarkopenia”, pojmowane jako utrata z wiekiem masy i siły mięśniowej, jest już pojęciem na tyle zakorzenionym w słownictwie medycznym, że dokonanie zmian w jego określaniu mogłoby przyczynić się do wielu nieporozumień na polu zarówno naukowym, jak i klinicznym [27].

\section{Patofizjologia i nozologia sarkopenii}

Sarkopenia u większości osób w wieku podeszłym może wynikać z różnych przyczyn, jak również jej następstwa mogą być wielorakie. Jeśli poza wiekiem i uwarunkowaniami genetycznymi nie ustalono żadnych czynników etiologicznych sarkopenii, definiuje się ją jako pierwotną lub związaną z wiekiem, a w przypadku znanego jej pochodzenia (jeden lub kilka czynników wywołujących) nazywa się ją sarkopenią wtórną, dzielącą się na trzy podgrupy:

- $\quad$ związana z aktywnością fizyczną,

- w przebiegu chorób przewlekłych,

- $\quad$ zależna od stanu odżywienia [19].

U większości osób w podeszłym wieku sarkopenia ma podłoże wieloczynnikowe. Jest konsekwencją zaburzonej homeostazy mięśni szkieletowych, a pośrednio i całego ustroju, względnej przewagi procesów katabolicznych nad anabolicznymi w starzejącym się organizmie. W etiopatogenezie sarkopenii uczestniczą różne procesy na poziomie biochemicznym, molekularnym, komórkowym i narządowym. Biosynteza białek, produkcja miofibryli i rabdomiocytów ulega stopniowemu spowolnieniu, dominują procesy proteolizy oraz apoptozy. W czasie procesu starzenia obserwuje się względ- 
nie niższe tempo produkcji białek niż zwiększoną ich degradację [28]. Więcej, organizm jako jednostka, jego nawyki i relacje z otoczeniem także warunkują rozwój sarkopenii $[19,29]$.

\section{Obraz kliniczny sarkopenii}

\section{Stadia sarkopenii}

Biorąc pod uwagę poziom zaawansowania sarkopenii, wyróżniono trzy jej stadia o znaczeniu klinicznym, ustalone m.in. w celu wyznaczenia metody terapeutycznej lub monitorowania efektów postępowania terapeutycznego [19]:

- $\quad$ presarkopenia - izolowane zmniejszenie masy mięśni szkieletowych,

- $\quad$ sarkopenia właściwa - utrata masy mięśniowej łącznie z osłabieniem mięśni lub obniżeniem sprawności fizycznej,

- $\quad$ ciężka postać sarkopenii - u pacjenta występują trzy elementy: spadek masy i siły mięśniowej oraz zmniejszenie sprawności ruchowej.

\section{Objawy i powikłania sarkopenii}

Objawy sarkopenii to osłabienie mięśniowe, szybko powstające zmęczenie, niska wytrzymałość na wysiłek, zaburzenia równowagi i koordynacji ruchowej, często - chudnięcie (wyjątek stanowi otyłość sarkopeniczna). Osłabienie przepony może zwiększać częstość przepukliny rozworu przełykowego i powodować utrudnienie oddychania i defekacji. Utrata masy mięśniowej łączy się ponadto ze zmniejszeniem rezerw energetycznych, czego dalszą konsekwencją mogą być zaburzenia termoregulacji i brak gorączki jako sygnału obronnego przy zakażeniach. Fakt ubywania zasobów aminokwasów i glikogenu może skutkować obniżeniem odporności i zaburzeniami gospodarki węglowodanowej. Chorzy z ciężką sarkopenią są niezdolni do normalnego codziennego funkcjonowania, powstaje zależność od innych osób. Często pojawiają się: apatia, depresja oraz zaburzenia lękowe [30].

Do innych powikłań sarkopenii zalicza się: rozwój osteoporozy, upadki i urazy (np. złamania kostne), zespół poupadkowy oraz jako kontinuum tego niekorzystnego procesu - zgon. Udowodniono, że niebezpieczeństwo złamania szyjki kości udowej jest częściej powiązane ze zredukowaną siłą i masą mięśniową aniżeli z masą całkowitą lub tłuszczową [31]. Sarkopenia zwiększa częstość hospitalizacji, stwarza niejednokrotnie konieczność zapewnienia opieki długoterminowej (domy opieki, zakłady opiekuńczo-lecznicze itp.), co powoduje poważne obciążenie budżetu systemu ochrony zdrowia [32]. Ważny jest także aspekt rodzinny i stawianie wyzwań fizycznych, psychicznych i materialnych dla osób bliskich pacjentów z ciężką sarkopenią.

\section{Diagnostyka sarkopenii}

Miarą sarkopenii jest ilościowe zdefiniowanie masy i siły skurczu mięśni szkieletowych oraz ocena kondycji fizycznej. Do tej pory nie ustalono jednoznacznej metody diagnostycznej. W 2010 roku Europejska Grupa Robocza ds. Sarkopenii u Osób Starszych (The European Working Group on Sarcopenia in Older People - EWGSOP) opracowała kryteria diagnostyczne dla sarkopenii. Rozpoznanie tego zespołu wymaga obiektywnie potwierdzonego kryterium 1 i dodatkowo udokumentowanego kryterium 2 lub 3 [19]:

- $\quad$ kryterium 1 - obniżona masa mięśniowa,

- $\quad$ kryterium 2 - zmniejszenie siły skurczu mięśni szkieletowych,

- $\quad$ kryterium 3 - spadek sprawności ruchowej.

Z kolei według rekomendacji European Society for Clinical Nutrition and Metabolism Special Interest Groups (ESPEN SIG), wydanych drukiem w 2010 roku, do zdiagnozowania sarkopenii może być wystarczające udowodnienie niskiej masy mięśniowej oraz ograniczenie prędkości chodu (poniżej 0,8 m/s w teście przejścia $4 \mathrm{~m})$ [33].

\section{Określanie masy mięśni szkieletowych}

Według zaleceń ESPEN SIG w celu ilościowej oceny masy mięśniowej należy - analogicznie do osteoporozy - przyjąć tzw. wskaźnik T-score, czyli stosunek masy mięśniowej danego pacjenta w wieku podeszłym do średniej masy mięśniowej osób młodych (18.-39. r.ż.). Za dolną granicę masy mięśni szkieletowych proponuje się uznać dwa standardowe odchylenia od średniej masy u osoby młodej, z uwzględnieniem płci i różnic etnicznych [33].

\section{Metody obrazowe}

Najbardziej dokładne techniki określenia masy mięśniowej opierają się na tomografii komputerowej (ang. computed tomography - CT) i obrazowaniu za pomocą rezonansu magnetycznego (ang. magnetic resonance imaging - MRI). Inną metodą pozwalającą odróżnić tkanki miękkie od tkanki tłuszczowej i od kości jest densytometria podwójnej energii promieniowania rentgenowskiego (ang. dual energy $X$-ray absorptiometry - DXA). Polega ona na skanowaniu całego ciała dwoma różnymi niskimi dawkami promieniowania $X$, co pozwala określić gęstość tkanek na zasadzie różnych prawidłowości osłabiania przez nie wiązek promieniowania jonizującego. Metoda ta charakteryzuje się dużą dokładnością, ale wadą są ograniczenia techniczne (niemobilny aparat, najwyższa masa ciała pacjenta badanego nie może przekroczyć $130 \mathrm{~kg}$ ). Baumgartner i wsp. przyjęli za dolną granicę normy dla masy mię- 
śniowej dwa odchylenia standardowe poniżej średniej wartości sumarycznej masy mięśni czterech kończyn (ang. appendicular skeletal muscle mass - ASM) u młodych dorosłych (między 18. a 40. r.ż.), osobno dla mężczyzn i kobiet w stosunku do wzrostu pacjenta. Jest to tzw. indeks masy mięśni szkieletowych (ang. skeletal muscle mass index - SMI; SMI = ASM/wzrost [kg/ $\left.\mathrm{m}^{2}\right]$ ). Densytometria podwójnej energii promieniowania rentgenowskiego jest szczególnie rekomendowana w diagnostyce otyłości sarkopenicznej [34].

\section{- Bioimpedancja elektryczna (ang. bioelectrical impedance analysis - BIA)}

Podaje objętość beztłuszczowej (ang. fat-free mass FFM) oraz tłuszczowej (ang. fat mass - FM) masy ciała poprzez dokonanie pomiaru oporności tkanek w czasie przepływu przez ciało prądu o natężeniu < 1 mA. Objętość beztłuszczowa składa się z tzw. suchej masy ciała (ang. lean body mass - LBM), przestrzeni płynowej pozakomórkowej oraz z elementów litych (minerały kostne i kolagen). Z kolei w skład LBM wchodzą narządy miąższowe bez tkanki tłuszczowej, czyli mięśnie i trzewia oraz układ odpornościowy. Uważa się, że to głównie LBM odpowiada za zachowanie homeostazy ustroju. Znaczną większość LBM stanowi masa mięśni, będących głównym obiektem deponowania białek, zachodzących procesów energetycznych i zmian metabolicznych w ustroju. Bioimpedancja elektryczna może być stosowana u osób obłożnie chorych i niechodzących. Wykazuje istotną korelację z wynikami MRI. Bioimpedancję elektryczną można wykorzystać do oceny ASM i indeksu masy mięśniowej zamiast DXA, pierwotnie wykorzystanej przez Baumgartnera i wsp. Opierając się na metodzie BIA, Janssen zaproponował inny sposób wyliczania indeksu masy mięśni szkieletowych [19, 35]: SMI = (masa mięśni szkieletowych / całkowita masa ciała) × 100 .

\section{- Pomiary antropometryczne}

Nie są zalecane w diagnostyce sarkopenii z powodu znacznych błędów interpretacyjnych. Pomiar obwodu ramienia czy łydki może być zaburzony przez obecność obrzęków, tkanki tłuszczowej lub łącznej na miejscu tkanki mięśniowej [36].

\section{- Badania biochemiczne}

Do biochemicznej oceny masy mięśniowej brakuje prostego testu. Stężenie kreatyniny w osoczu czy aktywność kinazy fosfokreatyny oszacowują ją dosyć niedokładnie, ponieważ jest wiele czynników, które na nie wpływają, np. działanie toksyn, odwodnienie, rabdomioliza czy hipoksja tkankowa. Względnie zadowalającym markerem masy mięśniowej może być oznaczenie dobowego wydalania kreatyniny lub 3-metylohistydyny z moczem. Klirens kreatyniny u osób w podeszłym wieku z zaawansowaną sarkopenią jest często przeszacowaną wartością, a niedoszacowaną - u pacjentów dobrze odżywionych z prawidłową masą mięśni [30].

\section{- Inne techniki}

Innymi metodami określenia masy mięśni szkieletowych są sposoby oceny częściowej lub całkowitej dystrybucji potasu w organizmie (w mięśniach szkieletowych znajduje się $>50 \%$ zasobów potasu). Wymagają one jednak drogiej aparatury i nie były powszechnie sprawdzane w badaniach klinicznych. Przy łóżku chorego mogłaby znaleźć zastosowanie echomiografia [19, 30].

\section{Ocena funkcjonalna}

Siła mięśniowa to zdolność do wykonywania pracy, która wiąże się z napięciem mięśnia wskutek szeregu procesów biochemicznych i neuronalnych. A zatem skurcz mięśnia jest wynikiem zamiany energii chemicznej na mechaniczną. Siła mięśniowa jest proporcjonalna do powierzchni przekroju mięśnia. Jest ona zależna od proporcjonalnego zaangażowania poszczególnych typów włókien mięśniowych oraz zdolności pobudzania jednostek motorycznych. Moc mięśniowa to zdolność do zrealizowania pracy z możliwie jak największą szybkością, a wytrzymałość mięśniowa - zdolność do rozwoju maksymalnej siły w jak najdłuższym czasie [19, 36].

\section{- Określanie siły mięśniowej}

Prostym sposobem badania siły mięśni jest pomiar izometryczny siły chwytu ręki (handgrip) za pomocą standardowego siłomierza ręcznego. Istotnie koreluje z siłą i mocą mięśni kończyn dolnych, z wielkością pola przekroju mięśnia trójgłowego łydki i z momentem obrotowym zginania kolan [19]. Niska siła chwytu ręki jest markerem niskiej aktywności ruchowej osoby w wieku podeszłym i lepszym czynnikiem prognostycznym niż masa mięśniowa [37]. Wykazano wyraźną zależność między siłą chwytu ręki a parametrami oznaczanymi metodą BIA skorygowanymi o wzrost. I tak, pozytywna korelacja z siłą uścisku dotyczy wskaźnika reaktancja/ wzrost, a negatywna - indeksu rezystancja/wzrost [38]. Bioimpedancja elektryczna może zatem być wykorzystana nie tylko do oceny masy, ale również funkcji mięśni szkieletowych, zwłaszcza u pacjentów, u których nie można zastosować izometrycznego pomiaru siły chwytu ręki. Jednym z istotnych czynników mogących przeszkodzić w dokładnym określeniu siły mięśniowej u pacjentów geriatrycznych są zaburzenia poznawcze.

\section{- Badanie mocy mięśni}

Moc mięśni w wieku podeszłym jest zwykle tracona szybciej niż wytrzymałość i jest ona lepszym czynni- 
kiem prognostycznym dla aktywności fizycznej niż siła mięśni. Oceniono, że moc mięśni dolnych kończyn jest odpowiednim predykatorem stanu funkcjonalnego starszych kobiet [39]. Moc prostowników kończyny dolnej można zmierzyć za pomocą profesjonalnej platformy mocy (Nottingham Power Rig). Wytrzymałość można mierzyć izometrycznie i izokinetycznie. Badania izometryczne maksymalnego skurczu dowolnego (ang. maximal voluntary contraction - MVC) mogą być wykonywane za pomocą stosunkowo prostego urządzenia. Dostępne na rynku siłomierze izokinetyczne umożliwiają zarówno pomiary izometryczne, jak i izokinetyczne jako moment siły koncentrycznej przy różnych prędkościach kątowych. Techniki używane w badaniach naukowych rzadko są używane w praktyce klinicznej ze względu na potrzebę stosowania fachowego sprzętu [19].

\section{- Ocena sprawności fizycznej}

Istnieje wiele testów oceniających sprawność ruchową osób w podeszłym wieku. Badania te powinny być systematycznie przeprowadzane (np. raz do roku) celem monitorowania postępu niepełnosprawności w przypadku ciężkiej sarkopenii. Jednym z testów, rekomendowanym przez EWGSOP, jest tzw. Short Physical Performance Battery (SPPB), który dokonuje oceny takich składowych aktywności fizycznej jak: wytrzymałość i siła mięśni, chód, równowaga. Test ten składa się z kilku części, które w sposób izolowany mogą być sprawdzone u danego pacjenta, dając znaczące dane na temat wydajności ruchu i będąc predykatorem niepomyślnych zdarzeń (m.in. inwalidztwa czy śmiertelności). Test SPPB obejmuje powtarzane 5-krotnie powstawanie z krzesła, test równowagi przy staniu z połączonymi stopami oraz przejście odległości $244 \mathrm{~cm}$. Za każdy etap można otrzymać 0-4 punkty. Chory leżący, wymagający stałej opieki, nie zdobędzie żadnych punktów, natomiast sprawny fizycznie uzyskuje 12 punktów [19, 40]. Bardzo przydatnym badaniem sprawności fizycznej jest ocena własnego tempa chodu pacjenta (prawidłowo $>0,8 \mathrm{~m} / \mathrm{s}$ ). Wynik testu 6-minutowego marszu może stanowić prognozę dla niepełnosprawności ruchowej czy dla zgonu [41]. Test „wstań i idź” na czas (ang. timed up and go - TUG) to wiele zadań ocenianych na czas, jak: powstawanie z pozycji siedzącej, przemierzenie odległości 3 m od miejsca siedzenia, obrót, powrót i siadanie. Uzyskanie czasu od 7 do 10 s to wynik prawidłowy. Na poważny brak sprawności ruchowej wskazuje czas $>20$ s. Warto zaznaczyć, że test można wykonywać u osób używających sprzętu ułatwiającego chodzenie $[19,42]$.

\section{Postępowanie terapeutyczne}

Ważnym zadaniem profilaktyczno-terapeutycznym jest zmiana stylu życia polegająca na zwiększeniu aktywności fizycznej w połączeniu z właściwie dobranym pod względem jakości sposobem żywienia.

\section{Fizykoterapia}

Efektywnym, prowadzącym do utrzymania autonomii i dobrego nastroju osób starszych sposobem walki z sarkopenią jest trening oporowy [43]. Wykonując ćwiczenia oporowe, można zyskać przyrost masy (dochodzi wówczas do wzrostu produkcji białek mięśniowych i objętości włókien typu II), a zwłaszcza siły mięśniowej. Istotą treningu siłowego jest stopniowa intensyfikacja oporu przeciwstawianego pracującym mięśniom. Ćwiczenia siłowe u osób starszych zwiększają zdolności do chodzenia, wchodzenia po schodach, zachowania równowagi, podnoszenia cięższych przedmiotów oraz zwiększają maksymalne pochłanianie tlenu (VO2 max). Są metodą bezpieczną i niezwykle skuteczną [44]. Prawdopodobnie optymalne efekty można uzyskać, stosując racjonalny trening mieszany oporowo-wytrzymałościowy. Izolowane ćwiczenia wytrzymałościowe zwiększają pułap tlenowy, unaczynienie i ukrwienie mięśni, nie stymulują natomiast biosyntezy białek. Stwarzają ryzyko urazu [45].

\section{Dieta i suplementy diety}

Stosowanie odpowiedniej diety bez treningu oporowego jest mało wydajne w przeciwdziałaniu sarkopenii. Przyjmowanie z każdym posiłkiem przez osoby starsze, podobnie jak w grupie osób młodszych, około 20-30 g białka daje maksymalny efekt stymulujący syntezę białek mięśniowych. Nie zauważa się takiego działania, jeśli białko przyjmowane jest razem z węglowodanami lub w mniejszej ilości z tłuszczami. Mało skuteczne okazuje się również przyjmowanie białka ponad zalecane dzienne spożycie. Suplementacja protein daje korzyści tylko przy wcześniejszych znacznych niedoborach białkowych w pożywieniu [30, 47]. Aminokwasy egzogenne (np. leucyna) spożywane regularnie mogą także wpływać na wzrost biosyntezy białek w mięśniach szkieletowych [46, 47]. Dieta bogata w tłuszcze, będące źródłem wolnych rodników, prowadzi do zaburzeń strukturalnych i czynnościowych mitochondriów. Okazuje się, że umiarkowana restrykcja kaloryczna (ang. calorie restriction - CR) z jednoczesnym niedopuszczeniem do niedożywienia daje pozytywne efekty w zapobieganiu utracie mięśni. Wydaje się, że taka strategia obniża produkcję reaktywnych form tlenu, stymuluje biogenezę i mechanizmy ochronne mitochondriów mięśniowych, równoważy autofagię i zapobiega apoptozie rabdo- 
miocytów. U gryzoni wykazano zmniejszenie częstości delecji mtDNA i nieprawidłowości w łańcuchu oddechowym po stosowaniu CR. Nadmierna restrykcja kaloryczna może natomiast skutkować wieloma objawami ubocznymi, takimi jak osłabienie, osteoporoza, depresja czy zanik libido [48]. Brak pewnych dowodów na pozytywne działanie diety bogatej w przedstawiane w mediach składniki do walki z sarkopenią jak: przyswajalne węglowodany o niskim indeksie glikemicznym $(<70 \%$ wartości dla glukozy), niestrawne oligosacharydy (np. hydrolizaty galaktomannanów, inulina, oligofruktoza), kreatyna, kwas a-ketoglutarowy, witamina $D_{3}$, ekstrakt z miłorzębu japońskiego czy spożywanie dużych ilości jaj.

\section{Farmakoterapia [28, 49]}

\section{Testosteron}

Testosteron to hormon steroidowy. Podawanie go starszym mężczyznom zwiększa masę mięśniową, ale nie powoduje poprawy funkcji mięśni. Mimo że istnieją przesłanki wskazujące na to, że siła starszych mężczyzn po podaniu dużych dawek testosteronu wzrasta, potencjalne zagrożenia przeważają nad korzyściami. Najczęściej obserwowane działania niepożądane to: agresywne zachowanie, powikłania zakrzepowo-zatorowe, bezdech senny, obrzęki obwodowe, ginekomastia, zwiększone ryzyko raka prostaty.

\section{Hormon wzrostu (ang. growth hormone - GH)}

Podawanie hormonu wzrostu osobom w podeszłym wieku zapewnia wzrost masy mięśniowej, zmniejszenie masy tłuszczowej i redukuje demineralizację kości. Suplementacja GH nie wywołuje wzrostu siły mięśniowej czy poprawy sprawności fizycznej. Niekorzystne skutki terapii to: zespół cieśni nadgarstka, obrzęki, bóle stawów, nietolerancja glukozy i cukrzyca. Niemałą wadą jest także jej wysoki koszt.

\section{Dehydroepiandrosteron (DHEA)}

Dehydroepiandrosteron (DHEA) to suplement diety. Jest on prekursorem hormonów płciowych, takich jak estrogen i testosteron, który przekształcany jest w tkankach docelowych. Ponieważ DHEA jest prekursorem w biosyntezie hormonów anabolicznych, suplementacja DHEA zarówno u mężczyzn, jak i kobiet może potencjalnie pomóc w zwiększeniu masy i siły mięśniowej bez potencjalnego ryzyka związanego z terapią testosteronową i estrogenową. Suplementacja DHEA u starszych mężczyzn i kobiet powoduje zwiększenie gęstości kości, stężenia testosteronu i estradiolu, nie powoduje jednak zmian w wielkości, wytrzymałości lub funkcjonowaniu mięśni. Dehydroepiandrosteron nie został jesz- cze sprawdzony w celu przeciwdziałania sarkopenii. Wymaga to dłuższego okresu obserwacji.

\section{Podsumowanie}

Problem sarkopenii w Polsce jest bagatelizowany. W tradycyjnej praktyce klinicznej badanie masy mięśniowej pogłębione o ocenę jej siły jest bardzo rzadko stosowane, brakuje również badań naukowych z tego zakresu. W literaturze polskojęzycznej odnaleziono tylko trzy prace poglądowe poruszające temat sarkopenii [50-52]. Sądzi się, że przyczyna takiego stanu rzeczy leży w braku świadomości rangi tego problemu, zarówno wśród pracowników ochrony zdrowia, jak i opinii publicznej. Wobec demograficznego wzrostu liczby osób starszych, również w strukturze społeczeństwa polskiego, sarkopenia zasługuje na uwagę. Profilaktyka, wczesne rozpoznanie i właściwe postępowanie terapeutyczne istotnie zwiększyłyby komfort życia osób dotkniętych tym problemem, a ochronę zdrowia uchroniłyby przed gigantycznymi wydatkami związanymi z następstwami sarkopenii, takimi jak niepełnosprawność, częste leczenie w szpitalach, pobyt w instytucjach opieki długoterminowej czy żmudny proces rehabilitacji [53]. Dokonany przegląd literatury prowadzi do wniosku, iż rozbudowywanie i przedstawianie wiedzy na temat sarkopenii u osób w wieku podeszłym wydaje się jak najbardziej zasadne.

\section{Piśmiennictwo}

1. Prognozy ludności na lata 2014-2050. Warszawa: Główny Urząd Statystyczny; 2014.

2. Krzymińska-Siemiaszko R. Wskaźnik niskiej masy mięśniowej w definiowaniu sarkopenii. Rozprawa doktorska. Poznań: Uniwersytet Medyczny im. K. Marcinkowskiego; 2014.

3. Mossakowska M, Broczek K, Życzkowska J, Klich-Rączka A, Wieczorowska-Tobis K. Sprawność funkcjonalna polskich stulatków. W: Kowaleski JT, Szukalski P (red.). Pomyślne starzenie się w świetle nauk o zdrowiu. Łódź: Zakład Demografii i Gerontologii Społecznej UŁ; 2008. 164-174.

4. Cruz-Jentoft AJ, Landi F, Topinková E, Michel JP. Understanding sarcopenia as a geriatric syndrome. Curr Opin Clin Nutr Metab Care. 2010; 13(1): 1-7.

5. Rolland Y, Czerwiński S, Abellan van Kan G, Morley JE, Cesari M, Onder G, Woo J, Baumgartner R, Pillard F, Boirie Y, Chumlea WM, Vellas B. Sarcopenia: its assessment, etiology, pathogenesis, consequences and future perspectives. J Nutr Health Aging. 2008; 12(7): 433-450.

6. Janssen I. The epidemiology of sarcopenia. Clin Geriatr Med. 2011; 27(3): 355-363.

7. Baumgartner RN, Koehler KM, Gallagher D Romero L, Heymsfield SB, Ross RR, Garry PJ, Lindeman RD. Epidemiology of sarcopenia among elderly in New Mexico. Am J Epidemiol. 1998; 147(8): 755-763.

8. Legrand D, Vaes B, Matheï C, Swine C, Degryse JM. The prevalence of sarcopenia in very old individuals according to the European consensus defi nition: insights from the BELFRAIL study. Age Ageing. 2013; 42(6): 727-734. 
9. Gariballa S, Alessa A. Sarcopenia: prevalence and prognostic significance in hospitalized patients. Clin Nutr. 2013; 32(5): 772-776.

10. Smoliner C, Sieber CC, Wirth R. Prevalence of sarcopenia in geriatric hospitalized patients. J Am Med Dir Assoc. 2014; 15(4): 267-272.

11. Vetrano DL, Landi F, Volpato S, Corsonello A, Meloni E, Bernabei R, Onder G. Association of Sarcopenia With Shortand Longterm Mortality in Older Adults Admitted to Acute Care Wards: Results From the CRIME Study. J Gerontol A Biol Sci Med Sci. 2014; 69(9): 1154-1161.

12. Landi F, Liperoti R, Fusco D, Mastropaolo S, Quattrociocchi D, Proia A, Russo A, Bernabei R, Onder G. Prevalence and risk factors of sarcopenia among nursing home older residents. J Gerontol A Biol Sci Med Sci. 2012; 67(1): 48-55.

13. Landi F, Liperoti R, Fusco D, Mastropaolo S, Quattrociocchi D, Proia A, Tosato M, Bernabei R, Onder G. Sarcopenia and mortality among older nursing home residents. J Am Med Dir Assoc. 2012; 13(2): 121-126.

14. Halil M, Ulger Z, Varlı M, Döventaş A, Oztürk GB, Kuyumcu ME, Yavuz BB, Yesil Y, Tufan F, Cankurtaran M, Saka B, Sahin S, Curgunlu A, Tekin N, Akçiçek F, Karan MA, Atlı T, Beger T, Erdinçler DS, Arıoğul S. Sarcopenia assessment project in the nursing homes in Turkey. Eur J Clin Nutr. 2014; 68(6): 690-694.

15. Kimyagarov S, Klid R, Fleissig Y, Kopel B, Arad M, Adunsky A. Skeletal muscle mass abnormalities are associated with survival rates of institutionalized elderly nursing home residents. J Nutr Health Aging. 2012; 16(5): 432-436.

16. Greenlund LJ, Nair KS. Sarcopenia - consequences, mechanisms, and potential therapies. Mech Ageing Dev. 2003; 124(3): 287-299.

17. Abellan van Kan G. Epidemiology and consequences of sarcopenia. J Nutr Health Aging. 2009; 13(8): 708-712.

18. Visser M, Schaap LA. Consequences of sarcopenia. Clin Geriatr Med. 2011; 27(3): 387-399.

19. Zamboni M, Mazzali G, Fantin F, Rossi A, Di Francesco V. Sarcopenic obesity: A new category of obesity in the elderly. Nutr Metab Cardiovasc Dis. 2008; 18: 388-395.

20. Janssen I. Evolution of sarcopenia research. Appl Physiol Nutr Metab. 2010; 35: 707-712.

21. Janssen I. Sarcopenia. W: Bales CW, Ritchie CS (red.). Handbook of Clinical Nutrition and Aging. Wyd. 2. New York: Humana Press; 2009.

22. Janssen I, Heymsfield SB, Wang ZM, Ross R. Skeletal muscle mass and distribution in 468 men and women aged 18-88 yr. J Appl Physiol. 2000; 89: 81-88.

23. von Haehling S, Morley JE, Anker SD. An overwiew of sarcopenia: facts and numbers on prevalence and clinical impact. J Cachexia Sarcopenia Muscle. 2010; 1: 129-133.

24. Rosenberg IH. Sarcopenia: origins and clinical relevance. J Nutr. 1997; 127(5 Suppl): 990-991.

25. Baumgartner RN, Koehler KM, Gallagher D, Romero L, Heymsfield SB, Ross RR, Garry PJ, Lindeman RD. Epidemiology of sarcopenia among elderly in New Mexico. Am J Epidemiol. 1998; 147: 755-763.

26. Manini TM, Clark BC. Dynapenia and Aging: an update. J Gerontol A Biol Sci Med Sci. 2012; 67(1): 28-40.

27. Cruz-Jentoft AJ, Baeyens JP, Bauer JM, Boirie Y, Cederholm T, Landi F, Martin FC, Michel JP, Rolland Y, Schneider SM, Topinková E, Vandewoude M, Zamboni M. Sarcopenia: European consensus on defi nition and diagnosis. Report of the European Working Group on Sarcopenia in Older People. Age Ageing. 2010; 39: 412-423.
28. Jones TE, Stephenson KW, King JG, Knight KR, Marshall TL, Scott WB. Sarcopenia - mechanisms and treatments. J Geriatr Phys Ther. 2009; 32: 39-45.

29. Cesari M, Pahor M. Target population for clinical trials on sarcopenia. J Nutr Health Aging. 2008; 12: 470-478.

30. Moulias R, Meaume S, Raynaud-Simon A. Sarcopenia, hypermetabolism, and aging. Z Gerontol Geriatr. 1999; 32: 425-432.

31. Roubenoff R, Harris TB, Abad LW, Wilson PW, Dallal GE, Dinarello CA. Monocyte cytokine production in an elderly population: effect of age and inflammation. J Gerontol A Biol Sci Med Sci. 1998; 53: M20-M26.

32. Bean N, Bennett KM, Lehmann AB. Habitus and hip fracture revisited: skeletal size, strength and cognition rather than thinness? Age Ageing. 1995; 24: 481-484.

33. Muscaritoli M, Anker SD, Argilés J, Aversa Z, Bauer JM, Biolo G, Boirie Y, Bosaeus I, Cederholm T, Costelli P, Fearon KC, Laviano A, Maggio M, Rossi Fanelli F, Schneider SM, Schols A, Sieber CC. Consensus defi nition of sarcopenia, cachexia and pre-cachexia: joint document elaborated by Special Interest Groups (SIG) "cachexia-anorexia in chronic wasting diseases" and "nutrition in geriatrics". Clin Nutr. 2010; 29: 154-159.

34. Evans EM, Misic MM, Mallard DM. A technique to assess body composition and sarcopenia using DXA: application for an obese population. Eur J Clin Nutr. 2010; 64: 218-220.

35. Janssen I, Heymsfield SB, Baumgartner RN, Ross R. Estimation of skeletal muscle mass by bioelectrical impedance analysis. J Appl Physiol. 2000; 89: 465-471.

36. Strzelecki A, Ciechanowicz R, Zdrojewski Z. Sarkopenia wieku podeszłego. Gerontol Pol. 2011; 3-4(19): 134-145.

37. Janssen I, Heymsfield SB, Ross R. Low relative skeletal muscle mass (sarcopenia) in older persons is associated with functional impairment and physical disability. J Am Geriatr Soc. 2002; 50: 889-896.

38. Lauretani F, Russo CR, Bandinelli S, Bartali B, Cavazzini C, Di lorio A, Corsi AM, Rantanen T, Guralnik JM, Ferrucci L. Age-associated changes in skeletal muscles and their effect on mobility: an operational diagnosis of sarcopenia. J Appl Physiol. 2003; 95: 1851-1860.

39. Foldvari M, Clark M, Laviolette LC, Bernstein MA, Kaliton D, Castaneda C, Pu CT, Hausdorff JM, Fielding RA, Singh MA. Association of muscle power with functional status in community-dwelling elderly women. J Gerontol A Biol Sci Med Sci. 2000; 55: M192-M199.

40. Norman K, Pirlich M, Sorensen J, Christensen P, Kemps M, Schütz $\mathrm{T}$, Lochs $\mathrm{H}$, Kondrup J. Bioimpedance vector analysis as a measure of muscle function. Clin Nutr. 2009; 28: 78-82.

41. Tomaszewski K, Matusik P, Chmielowska K, Nowak J, Parnicka A, Dubiel M, Gąsowski J. Otępienie a sprawność fizyczna pacjentów w podeszłym wieku mieszkających w wybranych domach opieki. Gerontol Pol. 2010; 18: 710-75.

42. Cesari M, Kritchevsky SB, Newman AB. Added value of physical performance measures in predicting adverse health-related events: results from the Health, Aging And Body Composition Study. J Am Geriatr Soc. 2009; 57: 251-259.

43. Roubenoff R. Physical activity, inflammation, and muscle loss. Nutr Rev. 2007; 65: S208-S212.

44. Kostka T. Trening siłowy (oporowy) w promocji zdrowia i rehabilitacji. Pol Merk Lek. 2002; 13: 520-523.

45. Beckers PJ, Denollet J, Possemiers NM, Wuyts FL, Vrints CJ, Conraads VM. Combined endurance-resistance training vs. endurance training in patients with chronic heart 
failure: a prospective randomized study. Eur Heart J. 2008; 29: $1858-1866$.

46. Dal Negro RW, Aquilani R, Bertacco S, Boschi F, Micheletto C, Tognella S. Comprehensive effects of supplemented essential amino acids in patients with severe COPD and sarcopenia. Monaldi Arch Chest Dis. 2010; 73(1): 25-33.

47. Paddon-Jones D, Rasmussen BB. Dietary protein recommendations and the prevention of sarcopenia. Curr Opin Clin Nutr Metab Care. 2009; 12: 86-90.

48. Marzetti E, Lees HA, Wohlgemuth SE, Leeuwenburgh C. Sarcopenia of aging: underlying cellular mechanisms and protection by calorie restriction. Biofactors. 2009; 35: 28-35.

49. Thomas DR. Sarcopenia. Clin Geriatr Med. 2010; 26: 331-346.

50. Galus K, Kozak-Szkopek E. Rozpoznawanie, zapobieganie i leczenie sarkopenii. Pol Merk Lek. 2011; 30(178): 274-276.

51. Parnicka A, Gryglewska B. Wyniszczenie nowotworowe a starcza sarkopenia. Gerontol Pol. 2006; 14: 113-118.

52. Krzymińska-Siemaszko R, Wieczorowska-Tobis K. Sarkopenia - w kierunku wystandaryzowanych kryteriów. Geriatria. 2012; 6: 46-49.
53. Janssen I, Heymsfield B, Ross R. Low relative skeletal mu scle mass (sarcopenia) in older person is associated with functional impairment and physical disability. J Am Geriatr Soc. 2002; 50: 889-896.

Artykuł przyjęty do redakcji: 22.10.2016

Artykuł przyjęty do publikacji: 22.11.2016

Źródło finansowania: Praca nie jest finansowana z żadnego źródła. Konflikt interesów: Autorzy deklarują brak konfliktu interesów.

\section{Adres do korespondencji:}

Przemysław Domagała

ul. Dębinki 7

80-211 Gdańsk

tel. kom.: 691211405

e-mail: coxbrikasta@gumed.edu.pl

Zakład Zarządzania w Pielęgniarstwie

Gdański Uniwersytet Medyczny 